\title{
Innovation policy for the mining sector in Brazil: a comparative analysis with Sweden centered on the interactions of involved agents
}

\author{
JoÃo Batista PAMPLONA ${ }^{12}$ \\ ana Carolina Penha ${ }^{1}$ \\ 1 Pontifícia Universidade Católica de São Paulo (PUC-SP) / Programa de Estudos Pós-Graduados em Economia Política, \\ SÃO PAULO - SP, BRAZIL \\ 2 Universidade Municipal de São Caetano do Sul (USCS) / Programa de Pós-Graduação em Administração, \\ SÃO CAETANO DO SUL - SP, BRAZIL
}

\begin{abstract}
This article examines the innovation policy for the mining sector in Brazil. The specific objectives are to characterize the innovation policy for the sector; identify the priorities of each agent (university, industry, and government) for policy formulation and execution, and to verify, in their perception, the challenges for improvement of the mining policy. The research adopts a qualitative approach, using the Triple Helix model of innovation as the theoretical background. The Brazilian case is analyzed using Sweden as a benchmark. Relevant strategic documents were collected and 18 interviews were conducted in Brazil and Sweden. The agents perceive the innovation policy in Brazil as something ephemeral, reactive and lacking in structure. The comparison between the Swedish and the Brazilian innovation agenda for the sector reveals that the Swedish is much broader, including technological and non-technological innovations. The Swedish agenda emphasizes the need to go beyond a strictly economic concern (business competitiveness and industrial policy) in the mining sector. Swedes highlight not only the environmental dimension but also the social dimension when proposing "socially sustainable mining regions." In both Brazil and Sweden, the low social acceptance of mining and the lack of long-term continuity of innovation policies are important challenges to be overcome.
\end{abstract}

Keywords: Mining. Non-technological innovation. Innovation policy. Brazil. Sweden.

\section{A política de inovação para o setor mineral no Brasil: uma análise comparativa com a Suécia centrada na interação dos agentes envolvidos}

\section{Resumo}

Este artigo tem por objetivo geral examinar a política de inovação para o setor mineral no Brasil. De modo mais específico, o artigo caracteriza a política de inovação para o setor no Brasil; identifica as prioridades que cada agente (universidade, empresa e governo); revela a formulação e execução da política; e verifica, na percepção deles, os desafios a superar para o aperfeiçoamento da política. Trata-se de pesquisa qualitativa. Foram levantados documentos estratégicos relevantes e foram realizadas 18 entrevistas (no Brasil e na Suécia). O referencial teórico é constituído pelo Modelo da Hélice Tríplice. A experiência brasileira é analisada tendo o caso sueco como referência. A política de inovação no Brasil para o setor é percebida pelos agentes como efêmera, reativa e pouca estruturada. A comparação da agenda sueca de inovação para o setor com a agenda brasileira revela que a primeira é muito mais ampla, incluindo inovações tecnológicas e não tecnológicas. Os suecos, ao contrário dos brasileiros, enfatizam a necessidade de ir além de uma preocupação estritamente econômica (competitividade empresarial e política industrial) para o setor. Os suecos destacam não só a dimensão ambiental, mas também a social, ao propor as "regiões mineiras socialmente sustentáveis". Tanto no Brasil como na Suécia, a baixa aceitação social da atividade e a falta de continuidade das políticas de inovação no longo prazo constituem desafios importantes a superar.

Palavras-chave: Mineração. Inovação não tecnológica. Política de inovação. Brasil. Suécia.

\section{La política de innovación para el sector mineral en Brasil: un análisis comparativo con Suecia centrado en la interacción de los agentes involucrados}

\section{Resumen}

El presente artículo tiene como objetivo general examinar la política de innovación para el sector mineral en Brasil. De forma más precisa, el artículo busca caracterizar la política de innovación para el sector en Brasil; identificar las prioridades de cada agente (universidad, empresa y gobierno); revelar la formulación y ejecución de la política; y verificar, según la percepción de dichos agentes, los desafíos a superar para el perfeccionamiento de la política. La investigación es cualitativa. Se levantaron documentos estratégicos relevantes y se realizaron 18 entrevistas en Brasil y Suecia. El modelo de triple hélice se constituye en marco referencial. La experiencia brasileña se analiza teniendo como referencia el caso sueco. La política de innovación en Brasil para el sector es percibida por los agentes como efímera, reactiva y poco estructurada. La comparación de la agenda sueca de innovación para el sector con la agenda brasileña revela que la agenda de Suecia es mucho más amplia, por incluir innovaciones tecnológicas y no tecnológicas. Los suecos, a diferencia de los brasileños, enfatizan la necesidad de ir más allá de una preocupación estrictamente económica (competitividad empresarial y política industrial) para el sector. Los suecos destacan no solo la dimensión ambiental, sino también la social, al proponer las "regiones mineras socialmente sostenibles". Tanto en Brasil como en Suecia, la baja aceptación social de la actividad y la falta de continuidad de las políticas de innovación a largo plazo constituyen desafíos importantes a superar.

Palabras clave: Minería. Innovación no tecnológica. Política de innovación. Brasil. Suecia. 


\section{INTRODUCTION}

Mining activity, like other natural resource intensive activities (agriculture, oil, etc.), is associated with what has been termed the "natural resource curse" in the literature (PAMPLONA and CACCIAMALI, 2017). The resource curse thesis consists of the idea that there is a negative relation between the abundance of natural resources and economic growth in the long run. The "abundance paradox", as well as the incongruity between abundance of resources and economic growth, not only refers to reduced economic performance, but also to other negative economic and political effects, as reprimarization of the economy (MILANEZ and LOSEKANN, 2016) and poor governance (ANDERSEN and JOHNSON, 2011).

Contrary to the idea of "natural resource curse", it is believed that resource-intensive industries can be activities with sufficient technological dynamism to promote innovation, diversification and sustainable development (PAMPLONA and CACCIAMALI, 2017). The emergence, diffusion and application of new technologies of greater transversality (as big data, new materials, biotechnology, etc.) in industries considered as less intensive in technology and knowledge, such as mining, have given rise to relevant changes, new outlooks and questions about the "paradox of abundance" (MESQUITA, CARVALHO and OGANDO, 2016).

The possibility that the resource-intensive industries can be a "ladder" for sustained economic development is only effective if there are measures that ensure dynamism, which means, innovation for those industries. According to the OECD (2012), having an innovation policy for strategic industries is essential in all phases of a country's economic development, specifically at the time of creation and diffusion of technologies relevant to economic growth. It should be noted, however, that the process of innovation in the economy must go beyond the propagation of technology (high-tech myopia), there should be concerns for the environmental and social spheres.

The Brazilian mineral industry has significant economic and strategic relevance for several other industries, for example civil construction, and for the development of new technologies. However, accidents as in Mariana-MG - rupture of the dam of Fundão in 2015 - show that the strategic importance of the sector is accompanied by relevant challenges. There are weaknesses in Brazilian mining due to deficiencies related to regulation and environmental and social issues.

To face such challenges, innovations for the mineral industry is required, articulated through an innovation policy that is a result of well-tuned interaction between the agents involved (university, business and government) and coordination between different interests. With innovations, specific challenges can be faced, such as the local socioeconomic reality and the demand for a more egalitarian (inclusive) society, as well as the adaptation of work environments, the promotion of an increasingly sustainable environment and the search for greater competitiveness of companies in this industry.

It is stressed the argument of the importance of innovation for the mineral industry by examples of economies that have transformed abundance of natural resources into a blessing, as with the Swedish experience. Sweden is a benchmark country in innovation performance. It is the second most innovative country - only behind Switzerland - In the ranking of the Global Innovation Index 2016 and is considered an economy, which is intensive in technology and innovation, although it is relatively small. Based on learning, knowledge generation and national policies ensuring innovation and its diffusion, Sweden has built an institutional framework that has enabled the coordination of the actions of three main actors in the industry (university, business and government) in order to build an environment for the mineral industry that sought not only business competitiveness but also emphasized environmental protection and social development.

This article aims to examine the innovation policy for the mineral industry in Brazil (excluding oil and gas) ${ }^{1}$. It considers the perception, action and interaction between the agents involved as an essential aspect, which, therefore, is chosen as the focus of the investigation. More specifically, the article characterizes the innovation policy for the industry in Brazil; identifies the priorities that each agent (university, business and government) reveals for policy formulation and execution; the article also verifies, in the agents' perception, the challenges to be overcome in order to improve policy. Thus, a general purpose of a pragmatic nature is presented, which does not seek to fill in or detect theoretical gaps, but contributes to improve the formulation and execution of public innovation policy for the mineral industry in Brazil.

\footnotetext{
${ }^{1}$ The exclusion of the oil and gas sector stems from its specificities (e.g., complex and self-regulatory policy). The National Science, Technology and Innovation Strategy 2016-2019 (BRASIL, 2016) considers energy industry and the minerals sector as different strategic industries.
} 
The research has a qualitative nature, using a critical and comparative analysis. The Swedish experience is assumed as a reference (success case) for the Brazilian experience. Data were obtained from secondary indirect sources (documents) and from direct sources (primary information obtained from 18 interviews with intentional sample). The theoretical framework is based on the Triple Helix Model (ETZKOWITZ and LEYDESDORFF, 1995; ETZKOWITZ, 2002; ETZKOWITZ and RANGA, 2012; ETZKOWITZ and ZHOU, 2017).

\section{LITERATURE REVIEW: CONTEXT AND THEORETICAL REFERENCES}

\section{CONTEXT}

Brazil stands out in the global scenario as one of the largest producers of mineral commodities, as iron ore and bauxite (UN COMTRADE, 2017). Owning the world's largest reserves of iron ore and niobium, Brazil ranked third in 2015 in the global iron ore production ranking. According to the US Geological Survey (USGS, 2017), the country holds $11.9 \%$ of the entire world iron reserve and ranks first in the niobium reserves ranking, holding $98.2 \%$ of all world niobium, equivalent to 10.7 million tons of ore only on national soil. The relevance of the numbers is not only related to the reserves in the national territory, but also to the Brazilian trade balance. In 2014, Brazil exported more than US\$ 34 billion and in the same year the country imported US\$ 6.8 billion in minerals such as potash, copper, salt, lime, cement and others (IBRAM, 2015, DNPM, 2016; COMTRADE, 2017).

Brazil has a recent trajectory regarding actions strictly focused on innovation, since Brazilian innovation policies have always been marked by the relationship between science \& technology and industrial policies. It is from the 2000s on that the country proceeds to more intensely prioritize innovation per se. Lei da Inovação (Law of Innovation - 2004) and Lei do Bem (Law of Good - 2005) comprise a formalized structure (regulatory framework), opening the door to a solid and mature innovation policy (SALERNO and KUBOTA, 2008).

Today, the Brazilian innovation policy can be characterized by the National Strategy for Science, Technology and Innovation (ENCTI) 2012-2015 and 2016-2019. Launched in 2012 by the Ministry of Science, Technology and Innovation (MCTI), ENCTI brought to the agenda of discussion the idea of approach innovation, in a structured way, for the main industries of the Brazilian economy. Mining, the main object of this article, is among the priorities presented by ENCTI. The general guidelines of ENCTI are: a) support for innovations in the productive industry, aiming to reduce the technological gap compared to developed countries; b) training and qualification of human resources for innovation; c) support to the most knowledge intensive industries; d) induction of clean production; and e) use of the state's purchasing power to promote innovation (BRASIL, 2012).

In addition to ENCTI, and in relation to the mineral industry, the government introduced the National Mining Plan - 2030 (PNM-2030) in 2011, which main objective is to guide long and medium term policies for the mineral industry. The plan is a different proposal from the mining plans launched earlier ${ }^{2}$ than the PNM-2030. The PNM-2030 guidelines are supported by three pillars: effective public governance; adding value; and knowledge densification and sustainability (BRASIL, 2011). In addition, in 2016, the National Bank for Economic and Social Development (BNDES) and the Financier of Studies and Projects (Finep) presented, in partnership, the Development, Sustainability and Innovation Plan in the Mining and Mineral Transformation Industry (Inova Mineral), a plan for the development of Brazilian technologies in the production chain of the mining and mineral processing industry. The project is part of one of Finep's main programs, Finep Inova Brasil, which provides to Brazilian companies financing for innovation and aims to support business plans that work with innovative products, processes and/or services.

Inova Mineral fits into what would be a policy of innovation for the mining sector, because it prioritizes the technological development of the mineral industry and supports innovation projects with technologies applicable in five thematic lines ${ }^{3}$.

\footnotetext{
${ }^{2}$ The plans previously launched to PNM-2030 were: a) Ten-Year Master Plan for the Evaluation of Mineral Resources of Brazil- I PMD (1965-1974); b) II TenYear Mining Plan- II MDP (1981-1990); and c) Multi-year Plan for the Development of the Mineral Industry- PPDSM (1994).

${ }^{3}$ Inova Mineral's thematic lines are: a) research and development of technologies and products focused on strategic minerals (cobalt, graphite, lithium, platinum group metals, molybdenum, niobium, silicon, thallium, tantalum, rare earths, titanium and vanadium); b) research and development (R\&D) of technologies and products focused on minerals with high commercial deficit (phosphate and potassium); c) R\&D, improvement and scaling of mining technologies (process technologies); d) technologies and processes for the reduction and mitigation of risks and environmental impacts; and e) development and pioneer production of machines, equipment, software and systems for mining and mineral processing (BNDES and FINEP, 2016).
} 
It is noted that Inova Mineral is a plan that focuses on innovation capable of increasing the competitiveness of companies in the sector. It has the merit of seeking to deepen the national mining chain (increase the effects of linkage) by seeking the development of national engineering and raising the technological level of local suppliers in the sector. Although decentralized and, most probably, as an emergency response to the problems brought by Samarco's accident in Mariana, Inova Mineral still has the merit of placing among its five thematic areas of projects, innovations related to the elimination and mitigation of risks and environmental impacts. In turn, there is a complete and worrying absence of stimulus to the innovations related to social problems in Inova Mineral (BNDES and FINEP, 2016).

Regarding mining in Sweden, it is considered one of the most relevant European countries. With mineral GDP at around 3\% in 2014 (USGS, 2017), the Swedish economy has stood out not only in the production of manufactures or industrialized products of mineral origin, but also in the exploitation of raw natural resources. The country controls $76 \%$ of the EU's iron ore production and is among the European leaders in the production of aluminum, copper, iron and silver (THE SWEDISH TRADE \& INVEST COUNCIL, 2016).

Sweden's National Innovation Strategy, created in 2012 and valid until 2020, prioritizes the formation of innovative regional environments and is based on six themes ranging from the Swedish citizen to businesses, public services and the environment. The idea is for innovation to be present in all areas of the country in order to stimulate sustainable development and overcome the inherent challenges of an economy facing a climate and labor-constrained economy (GOVERNMENT OFFICES OF SWEDEN, 2012).

The main banner of the Swedish Mineral Strategy is "Sweden's sustainable use of mineral resources that creates growth throughout the country" (GOVERNMENT OFFICES OF SWEDEN, 2011, our translation). In 2014, the country developed a strategy for the mineral industry known as the Strategic Research and Innovation Agenda for the Swedish Mining Industry and Metal Producing Industry (STRIM), a document aimed at the industry that seeks not only corporate competitiveness, but also environmental protection and social development. STRIM is divided into seven main thematic areas ${ }^{4}$, in which the social and environmental character of the Swedish innovation policy for mining is highly marked.

\section{THEORETICAL REFERENCE}

The design of innovation policies emerged in the mid-1990s from the need to expand the concept of science and technology policies, often linked to industrial policies. Until then, there was no specific characterization for policies aimed at fostering innovation. The Organization for Economic Co-operation and Development (OECD) presented its first report on innovation policies in 2006 with the Innovation Policy Report for Switzerland (OECD, 2006). Reflections on the concept of innovation policies and how it can be analyzed is still recent (FAGERBERG, 2015a, 2015b).

The World Bank, in its platform for the promotion of innovation policies in different countries (The Innovation Policy Platform), defines what is meant by policy:

Policy is, by definition, goal-oriented, constituting deliberate courses of action in pursuit of some stated aim. Policy goals range from being very broad, for example, improving workforce skills, to being more specific, for example, increasing the number of female graduates in engineering schools. Policy goals emerge from the agenda-setting activities of policy arenas. They are shaped by those interests participating in such arenas, as well as by commonly-held ideas, beliefs and conceptual models (IPP, 2017).

More specifically, it is assumed that an innovation policy can be defined as "all the combinations of actions that are taken by public organizations and influence the processes of innovation" (EDQUIST and BORRÁS, 2003, p. 6). It is assumed that an innovation policy assemble a set of measures aimed at a specific objective and that, together, result in the stimulation of innovation for a given economy or industry. An effective innovation policy addresses the general innovation environment,

${ }^{4}$ STRIM's thematic areas are: a) deep and innovative exploitation of metals; b) business competitiveness in mining; c) mineral processing; d) recycling and metallurgy; e) recovery and good environmental performance; f) attractive workplaces; and (g) gender equality (GOVERNMENT OFFICES OF SWEEDEN, 2011). 
which encompasses social, environmental and economic aspects, and goes well beyond the traditional science and technology policy that involves many government agencies (WORLD BANK, 2010).

To overcome the issue of incorporating several and varied elements in the analysis, it is accepted that the formulation and execution of an innovation policy can be studied in an approach emphasizing the interaction of agents as a central element, as is the case of the Triple Helix Model. The model of Henry Etzkowitz and Loet Leydesdorff focuses on three agents, understanding how each agent relates in the interaction among them and also concerns what happens in the internal and superimposed spaces of the boundaries of the institutional spheres.

The Triple Helix Model has important contributions to understand the interaction between the main agents involved in the formulation and execution of the innovation policy. Formulated by Etzkowitz and Leydesdorff (1995), the model brings in its drawing the figures of university, business and government interacting with each other and generating new technologies or innovations. The interactions university/company/government compose a "triple helix" of innovation and their interactions through triad relations favor innovation and institutionalization (BERGER and LUCKMANN, 1967).

The purpose of the triple helix is to provide an innovative environment in which the state, academia and companies connect to create innovation from hybrid institutions. The environment will be composed of companies, laboratories and governmental initiatives and academic research groups that together will form trilateral ties aimed at economic development, based on knowledge and operating in different areas and with different levels of technology:

The Triple Helix identifies people and relationships, the institutional arrangement and the dynamic mechanisms that are fundamental to innovation and entrepreneurship. The Triple Helix states that the theoretical framework of innovation originated in the industry, is strengthened by the inclusion of the government's role, which takes it one step further, and connects innovation and entrepreneurship to the university as a fundamental source of new (ETZKOWITZ and ZHOU, 2017, p. 31).

The triple helix denotes not only the relationship between university, industry and government, but it also highlights the cooperation between the three agents, in which the transfer of knowledge from one part to the other has a very important role, because it is through this exchange that the agents can achieve better results in the research process. For this reason, the transfer of knowledge must be structured and encouraged from the beginning of the policy formulation, so then, a frequent and open communication is established between the groups.

In addition, Etzkowitz (2002) points out that interaction between three agents can result in collaboration and conflict moderation. This result of interaction, according to the author, occurs in triad relations, since in relations with three agents the capacity to transform a tension or a conflict of interest into collaboration is much greater than in the relations dyads. On the tripod, the chances for more dialogue and direction to a point in common increase compared to interactions with only two actors.

\section{METHODOLOGY}

The general goal of the research presented in this article was to critically analyze the innovation policy for the mineral industry in Brazil, compared to Sweden, having as data source the main strategic documents related to the innovation policies for the industry in the two countries, and especially the perception of the agents involved: government, university and business. It is assumed that the perception, action and interaction of agents are an essential condition for the proper functioning (formulation and execution) of innovation policy.

It is a qualitative research aligned with the recommendations of Myers (2013). The qualitative approach methods are designed to help researchers understand what people are talking about and doing. They are also used to understand the multiple context in which decisions are made and actions taken. Qualitative research studies real situations. Thus, good qualitative studies need to be actively engaged with people in real organizations, with their complex and non-quantifiable issues (MYERS, 2013). 
The data, collected during 2017, were originated from an indirect (secondary) source and a direct (primary) source. In the first case, the main strategic documents characterizing innovation policies for the mineral industry in Brazil and Sweden were drawn up. They were: Development, Sustainability and Innovation Plan in the Mining and Mineral Transformation Industry (Inova Mineral) (BNDES and FINEP, 2016); National Mining Plan 2030 (PNM-2030) (BRASIL, 2011); National Strategy for Science, Technology and Innovation (ENCTI) in the 2012-2015 and 2016-2019 versions (BRASIL, 2012, 2016); Strategic Research and Innovation Agenda for the Swedish Mining Industry and Metal Producing Industry (STRIM) (VINNOVA, 2017a, 2017b); The Swedish Innovation Strategy (GOVERNMENT OFFICES OF SWEDEN, 2011).

In the second case, semi-structured interviews were conducted, personally in Brazil and Sweden, with an intentional sample which size was defined as follows: three representatives for each organization of the triad (university, government, company ${ }^{5}$ ), relevant to innovation in the industry, in Brazil and in Sweden. The size of the sample totaled 18 people (each interviewed only once $\left.^{6}\right)(3 \times 3 \times 2$, i.e.: 3 agents for each organization of the triad for the 2 countries). This composition of the sample made it possible to triangulate opinions between and within each type of organization of the triad. The list of respondents and their respective organizations is shown in Box 1 . The names of respondents were omitted and they are identified by codes (see Box 1) in the analysis of results.

The collected data were submitted to content analysis, adapting the phases suggested by Bardin (2016) ${ }^{7}$. In the pre-analysis, a corpus of content was constituted represented by the strategic documents that characterize the innovation policies for the industry in Brazil and Sweden and by the interviews of the 18 selected agents. Still in this phase, the problematization was consolidated (questions 4.1 and 4.2 in Box 2). In the exploration of the corpus, 7 thematic categories were established for questions 4.1 and 5 for question 4.2. In the interpretation of the results, the grouped content, according to the thematic categories, could be analyzed in a critical and comparative way - according to Bardin (2016), this is the moment of intuition, reflection and criticism. The goal was unveil the latent content and made interpretations and connections with the context. The Swedish experience with innovation policy for the mineral industry was considered a benchmark (success case) for the comparative analysis with the Brazilian experience - as it is justified in the previous pages of this article.

\section{Box 1}

\section{Interviewees list}

\begin{tabular}{|c|c|c|c|c|c|}
\hline \multicolumn{4}{|c|}{ Interview Data } & \multicolumn{2}{|c|}{ Analysis Code } \\
\hline Agent & Type of Agent & $\begin{array}{l}\text { Interview } \\
\text { Date }\end{array}$ & Position of Interviewee & Brazil & Sweden \\
\hline Government of Sweden & Government & 02/06/2017 & Scientific Officer & - & Gswe1 \\
\hline Business Sweden & Government & 05/06/2017 & Mining Project Manager & - & Gswe2 \\
\hline $\begin{array}{l}\text { Swedish Innovation } \\
\text { Agency (VINNOVA) }\end{array}$ & Government & $21 / 06 / 2017$ & Project Manager & - & Gswe3 \\
\hline $\begin{array}{l}\text { Lulea University of } \\
\text { Technology (LTU) }\end{array}$ & University & $21 / 06 / 2017$ & Professor & - & Uswe1 \\
\hline $\begin{array}{l}\text { Lulea University of } \\
\text { Technology (LTU) }\end{array}$ & University & $27 / 06 / 2017$ & Professor & - & Uswe2 \\
\hline $\begin{array}{l}\text { Center for Mining and } \\
\text { Advanced Metallurgy- } \\
\text { University de Lulea }\end{array}$ & University & $27 / 06 / 2017$ & Director & - & Uswe3 \\
\hline SvenMin & Company & 27/06/2017 & CEO & - & Eswe1 \\
\hline Boliden & Company & 05/09/2017 & Innovation Director & & Eswe2 \\
\hline
\end{tabular}

${ }^{5}$ It should be noted that the selected companies are those composing the core of the minerals production chain, that is, mineral extraction and processing companies.

${ }^{6}$ The interviews were conducted from June to September 2017, in Portuguese with the Brazilians and in English with the Swedes. In the analysis of the results, the testimonies of the Swedes were translated into Portuguese.

${ }^{7}$ Bardin (2016) points out that content analysis is organized according to "three poles": a) pre-analysis; b) exploitation of the material; and c) treatment of results, inference and interpretation. 
Continue

\begin{tabular}{|c|c|c|c|c|c|}
\hline \multicolumn{4}{|c|}{ Interview Data } & \multicolumn{2}{|c|}{ Analysis Code } \\
\hline Agent & Type of Agent & $\begin{array}{l}\text { Interview } \\
\text { Date }\end{array}$ & Position of Interviewee & Brazil & Sweden \\
\hline LKAB & Company & 06/09/2017 & Manager of External R\&D Projects & - & Eswe3 \\
\hline BNDES & Government & $10 / 08 / 2017$ & Analyst- Mining and Metals Department & Gbr1 & - \\
\hline FINEP & Government & $17 / 08 / 2017$ & $\begin{array}{c}\text { Analyst- Oil, Mining and Steel } \\
\text { Department }\end{array}$ & Gbr2 & - \\
\hline $\begin{array}{l}\text { Ministry of Science, } \\
\text { Technology, Innovation } \\
\text { and Communication } \\
\text { - MCTIC }\end{array}$ & Government & 05/09/2017 & $\begin{array}{l}\text { General Coordinator-Energy, Fuels, Oil } \\
\& \text { Gas, Mineral Resources, Mobility and } \\
\text { Sanitation }\end{array}$ & Gbr3 & - \\
\hline UFJF & University & $17 / 08 / 2017$ & Professor & Ubr1 & - \\
\hline UFSC & University & $17 / 08 / 2017$ & Professor & Ubr2 & - \\
\hline UFMG & University & 21/09/2017 & Professor & Ubr3 & - \\
\hline Vale S.A. & Company & $10 / 08 / 2017$ & CEO & Ebr1 & - \\
\hline $\begin{array}{l}\text { Brazilian Institute of } \\
\text { Mining }\end{array}$ & Company & 19/09/2017 & Manager & Ebr2 & - \\
\hline Anglo American Brasil & Company & 25/08/2017 & CEO & Ebr3 & - \\
\hline
\end{tabular}

Source: Elaborated by the authors.

\section{PRESENTATION AND ANALYSIS OF RESULTS}

The analysis of the results is based on the interpretation of the content of the interviews and the strategic documents of the innovation policy for the industry in both countries. The primary research was based on an interview script (open questions), applied to the agents involved in the innovation process for Brazilian and Swedish mining (university, company and government), which highlights two questions related to the purpose of this article:

a) What are the priority areas that agents identify for innovation in the mineral industry?

b) What are the obstacles and challenges perceived by agents to promote innovation in the mineral industry?

Box 2 presents the structure (model) of the analysis of results. 
Box 2

\section{Results analysis mode}

\begin{tabular}{|c|c|c|c|c|c|}
\hline \multirow{2}{*}{\multicolumn{2}{|c|}{ Results Analysis Model }} & \multicolumn{4}{|c|}{ Primary and secondary sources } \\
\hline & & \multirow{2}{*}{$\begin{array}{l}\text { Interviews } \\
\text { from Brazil }\end{array}$} & \multirow{2}{*}{$\begin{array}{l}\text { Interviews } \\
\text { from Sweden }\end{array}$} & \multirow{2}{*}{$\begin{array}{l}\text { Documents from } \\
\text { Brazil (ENCTI and } \\
\text { Inova Mineral) }\end{array}$} & \multirow{2}{*}{$\begin{array}{l}\text { Documents from } \\
\text { Sweden (STRIM) }\end{array}$} \\
\hline Questions & Thematic Categories & & & & \\
\hline \multirow{7}{*}{$\begin{array}{l}\text { 4.1. What are the priority } \\
\text { areas that agents identify } \\
\text { for innovation in the mine- } \\
\text { ral industry? }\end{array}$} & $\begin{array}{l}\text { Technological } \\
\text { innovation }\end{array}$ & $x$ & $x$ & $x$ & $x$ \\
\hline & $\begin{array}{l}\text { Non-technological } \\
\text { innovation }\end{array}$ & & $x$ & & $x$ \\
\hline & Industrial Policy & $x$ & & & \\
\hline & Industry 4.0 & $x$ & & $x$ & \\
\hline & $\begin{array}{l}\text { Gender Equality in the } \\
\text { Mineral Industry }\end{array}$ & & $x$ & & $x$ \\
\hline & Attractive workplaces & & $x$ & & $x$ \\
\hline & Environmental Concern & $x$ & $x$ & $x$ & $x$ \\
\hline \multirow{5}{*}{$\begin{array}{l}\text { 4.2. What are the obsta- } \\
\text { cles and challenges noticed } \\
\text { by the agents to promote } \\
\text { innovation in the mineral } \\
\text { industry? }\end{array}$} & Policy continuity & $x$ & $x$ & & \\
\hline & Long term policies & $x$ & $x$ & & \\
\hline & $\begin{array}{l}\text { Dislikes and mistrust } \\
\text { between agents }\end{array}$ & $x$ & & & \\
\hline & $\begin{array}{l}\text { Social acceptance of } \\
\text { mineral activity }\end{array}$ & $x$ & $x$ & & \\
\hline & $\begin{array}{l}\text { Intellectual property of } \\
\text { innovations }\end{array}$ & $x$ & $x$ & & \\
\hline
\end{tabular}

Source: Elaborated by the authors.

\section{What are the priority areas that agents identify for innovation in the mineral industry?}

In general, when we look at the strategies or initiatives for innovation in mining in both countries, the contrast is easily observed.

On the Brazilian side, the priorities contained in the documents and those cited by the agents vary between technologies for product improvement and process technologies. In other words, while the Brazilian innovation policy is still very focused on the industrial and technological issues, with little progress in the environmental and social sense, the Swedish strategy is more concerned with the development of sustainable mining regions not only from the strictly environmental point of view, but also from the social point of view. This implies understanding not only of technological innovations that increase productivity, reduce risks of investment and reduce the environmental impact, but also the attractive working environment and the training of those who work in the mines. This involves the inclusion of the female gender in the industry. In this regard, the differences with the Swedes are striking (Box 3). 


\section{Box 3}

Comparison between thematic areas of the Strategic Research and Innovation Agenda for the Swedish Mining Industry and Metal Production Industry - STRIM (Sweden) and the Development, Sustainability and Innovation Plan in the Mining and Mineral Transformation Industry - Inova Mineral (Brazil)

\begin{tabular}{|c|c|c|}
\hline Áreas da Agenda & Inova Mineral (Brasil) & STRIM (Suécia) \\
\hline $\begin{array}{l}\text { Technology and methodology } \\
\text { for exploration and evaluation } \\
\text { of new mines and minerals }\end{array}$ & $\begin{array}{l}\text { R\&D of Strategic Mineral Technologies and } \\
\text { Products "Portadores do Futuro": Cobalt, } \\
\text { Graphite, Lithium, Group of Platinum, } \\
\text { Molybdenum, Niobium, Silicon (Solar Grade), } \\
\text { Thallium, Tantalum, Titanium and Vanadium; } \\
\text { R\&D for products with trade deficit. }\end{array}$ & $\begin{array}{l}\text { To provide the industry with a type of } \\
\text { innovative technology enabling the exploration } \\
\text { of deep mines and a 3D model for deep crusts } \\
\text { enabling a detailed planning before exploration. }\end{array}$ \\
\hline $\begin{array}{l}\text { Efficient processing of } \\
\text { mineral resources }\end{array}$ & $\begin{array}{l}\text { Development and pioneer production of } \\
\text { machines, equipment, software and systems } \\
\text { for mining and mineral processing. }\end{array}$ & $\begin{array}{l}\text { Development of new products with higher } \\
\text { added value; to increase the degree of } \\
\text { automation; integrate the controls of the } \\
\text { several areas and stages of mining into a } \\
\text { single plant. }\end{array}$ \\
\hline $\begin{array}{l}\text { Reuse and recycling as part of } \\
\text { a sustainable society }\end{array}$ & $\begin{array}{l}\text { To foster the development of solutions capable } \\
\text { of reducing or mitigating the environmental } \\
\text { risks and impacts of mining activities. }\end{array}$ & $\begin{array}{l}\text { To reduce Co2 emissions through conscious } \\
\text { energy consumption; to decrease dependence } \\
\text { on raw materials in natura; stabilization of } \\
\text { waste to reduce environmental hazards and } \\
\text { damage; reduction of water use in the drying } \\
\text { process and tonnage of minerals; reduction of } \\
\text { material deposit in the environment. }\end{array}$ \\
\hline $\begin{array}{l}\text { Education of people, gender } \\
\text { equality and opportunities }\end{array}$ & Not applicable & $\begin{array}{l}\text { To increase the diversity and opportunity of } \\
\text { jobs for men and women; to promote gender } \\
\text { equality in the mineral industry; to increase } \\
\text { employment opportunities in rural and sparsely } \\
\text { populated areas; decrease human exposure } \\
\text { during mineral exploration. }\end{array}$ \\
\hline Attractive workplaces & Not applicable & $\begin{array}{l}\text { To improve safety and working conditions } \\
\text { in mining; reduction of fatal accidents in } \\
\text { mines and accidents at work; to ensure job } \\
\text { satisfaction. }\end{array}$ \\
\hline
\end{tabular}

Source: Elaborated by the authors.

However, contrary to the traditional emphasis given only to business and sectorial competitiveness for mining in Brazil in 2016, Inova Mineral introduced changes in the usual look at Brazilian mining. Unlike all governmental strategies previously prepared, the program brings among the thematic lines the concern with the environment in the surroundings of the mines. Although it is a response to the Mariana accident in 2015, there are signs of changes in agents' priorities for the Brazilian mineral industry:

This disaster of Mariana ignited the red alert, because, just so you have an idea, only in Minas are at least 400 large dams and there are people who think that the dam of Fundão, which broke, was not the worst. That is, we have a huge potential problem, of course, industries should be more careful, but we have seen that the solution is not to accumulate tailings, so this has opened attention to them ... I will not go say it did not exist because there were already industries that discussed this, but one thing is you have industries inside thinking about changing the procedures and another is the industry itself, CEOs thinking: "let's solve it there" [...] I think that a big problem is change the procedures, but once you go to institute new procedures and overcome this step, then you can start at a better level (Agent Ubr3, 2017). 
Regarding to technological innovations, what appears to be a priority for Brazilian agents in the three spheres is mining 4.0 and the internet of things (IOT). The development of mining 4.0 and the discussions about its effects are still recent in Brazil, but it is already signaling the concern to develop technologies internally for the industry and not only depend on other countries of reference in the subject, such as Australia, so that the mining 4.0 advance in Brazil:

Another area that I think has an important perspective is the so-called "mining 4.0", which is linked to the internet of things ... [...] So this is a line that we have also worked on. And in this direction FIEMG (Federation of Industries of the State of Minas Gerais), it is even with an initiative called, I think of "mining internet", that is, the industry is assuming this and I have strongly emphasized that they should develop their own technologies (Agent Ubr3, 2017).

These days I attended an event [in], which was, addressed the issue of industry 4.0, the internet of things. It was already for us to have this here in the mining, this could be a way. In this event, they talked about gaining productivity by $30 \%$, which would be great for the industry and for the company. However, we are still far behind (Agent Ebr3, 2017).

Automation towards the 4.0 industry and the internet of things, more in that sense, process control, process of processing and processing... so in all this there is a great leap, a great promise for mining. Therefore, the priority areas certainly are: environment, you cannot talk about that; IT and this issue of social acceptance. I would stick with these three areas (Agent Gbr2, 2017).

In turn, issues not related to technological innovation and environmental issues, as attractive workplaces, vocational training, gender equality and social conditions around the mines, are not yet a priority for Brazilian mining. The interviews with actors involved in mineral activity in Brazil explain that non-technological innovation (environmental, organizational, social) still depends on legal requirements - it is far from being an initiative of the industry in Brazil:

I think the other topics in the discussion of innovation other than technology end up coming through enforcement, honestly. It is obvious that the first step will be given, therefore, by a report of best practices, supply chain standards, a management system that measures the quality of the environment, the safety issue, those things... This represents a breakthrough, for sure. But we still do not have an awakening, so "let's do it because I want it," or "let's do it because it's good and I'll even make money from it" (Agent Gbr2, 2017).

From the Swedish perspective, STRIM's innovation strategy for the mineral industry, when compared to ENCTI and Inova, makes it very clear that the Swedish innovation policy for the industry seeks not only business competitiveness, but also social and environmental development sustainable development. Innovation in mining is considered essential, and such an argument is made when it is observed that innovation within the industry is not limited to technology - instead, it is encouraged to develop certain localities in order to guarantee "socially sustainable mining regions" and is also used in the discussion of more transversal themes, such as socio-environmental sustainability within the mining industry and training of people. STRIM highlights topics such as recycling, recovery and good environmental performance, as well as topics such as safe workplaces, attractive workplaces, gender equality and social diversity.

In the interviews with the Swedish agents, it is also clear that the priorities of the innovation policy for the mineral industry must go beyond the purely technological dimension. This thesis, which materializes with what STRIM calls "socially sustainable mining regions", is embodied in the discourse of both agents linked to universities and government as well as companies:

The issue of sustainability is at the top of our list of priorities. Because of what exactly happened in Brazil (Mariana accident) [...] which can be very dramatic, and something similar happened here too, so safety first. The environment is one of our key issues, so we can never put it off our agenda (Agent Eswe3, 2017).

Today, we have companies that combine all this ... But it has not always been that way. I think Brazil can still go through this process and focus on areas beyond technology (Agent Eswe2, 2017). 
We do not have these (financial) incentives to be sustainable, but we have laws, demanding laws ... And besides, we have social licenses that are strict in Sweden. Citizens do not work for companies that destroy the environment, kill nature or have a bad work environment, so it's clear that we need to be good (Agent Uswe2, 2017).

They (STRIM) wanted to emphasize the competitiveness of the industry, sustainable development, sustainable mining, then ... those are, in general, the objectives (of politics) ... They have technical as well as non-technical areas such as areas in which gender is discussed in mining, social topics ... So this is what is interesting when we look at all the innovation strategy programs (Agent Gswe3, 2017).

\section{What are the obstacles and challenges perceived by agents to promote innovation in the mineral industry?}

One of the main difficulties presented for both Brazil and Sweden is the lack of continuity of policies or strategies to consolidate innovations in the mineral industry. Agents pointed out this problem from the three spheres and, although the concept of "innovation policy" is treated differently by Brazil and Sweden, the agents of the two countries consider it important to have lasting and long-term initiatives for the industry.

Despite the efforts made during the 1990s and 2000s to coordinate actions to promote the Brazilian mineral industry, the industry still lacks an official strategy that brings together all initiatives (Inova Mineral, PNM-2030, ENCTI), which connect all three agents and list the strategic objectives for mineral industry development through innovation. The few Brazilian initiatives in this direction are considered insufficiently consistent and do not connect adequately. The agents consider the initiatives Inova Mineral and ENCTI to be ephemeral and uncertain, and can be characterized, above all, as seasonal, typical of only a certain government:

Innovation is not done in the short term and in Brazil, one only thinks about the short term. We live to meet the demands of the present and you cannot think something for the future. And this fueled by the factors I just quoted. That is why we do not have a policy of innovation for structured mining. Not to say that we have nothing, we have isolated initiatives (Agent Ebr2, 2017).

For the Swedish case, the lack of continuity of policies is also seen as an obstacle that must be overcome by the commitment to continue the initiatives (policies) for the industry, even when there is a change of government. It was alleged that when the current agenda loses its strength, many projects, although consistent, end up being deprecated:

A challenge, well, should be the long-term commitment. And not just have a program for 5 years and then stop; we must have something that comes from it, and I do not know ... It's not an obstacle, but it's a challenge. So for a very good financing system, this is always a challenge. The present moment is very good, but that is now. In 5 years you have to fight it ... You cannot have an agenda, then stop and never go back to it. It has to be always on the move. This is actually the second version of STRIM, and before STRIM we had other strategies that resulted in this agenda, so ... (Agent Uswe1, 2017).

Due to the lack of continuity, it is argued that there is not enough time for the mineral industry in Brazil to mature policies and/or measure results. In addition, it was also pointed out in the interviews that the lack of a long-term policy could affect the partnership between the agents, since an initiative to cooperate to carry out an innovation project that does not present guarantees to remain for a longer time ends not being attractive enough.

Within the pattern of lack of continuity of policies presented by agents, the problem of timing in the interaction among agents in Brazil was also recurrently cited in the interviews. There is no time, on the part of the companies, to expect an innovation project to mature in the research center of a university. Brazilian mineral companies claims urgency for the results, which reinforces, once again, the absence of a culture of long-term collaborative research. Innovation, for Brazilian companies, still seems to be designed only for the increase of the mineral production. The university, on its turn, does not have the resources to develop an innovation for the mineral industry that has all the phases already completed, from diagnosis to problem solving: 
On the other hand, the interaction you have with CNPq, FAPESP, FAPEMIG or FINEP, if you need and say "ah, I need more time", you will have more time. In the industry, we do not have the same flexibility. The industry wants that in the stipulated time, keep the deadline, in the budget, that is what occurs. So, I would say that the dynamic of an average Brazilian researcher is still incompatible with the dynamic of the an average Brazilian industry (Agent Ebr1, 2017).

Another aspect that we can analyze from this dyad relationship (university and company) are the existing tensions that generate schisms and mistrust. Even when there are resources and interest in developing a project, there is something like strangeness, discomfort between the agents in the relationship between university and company. This seems to be in line with Etzkowitz's (2002) argument that relations between two actors, dyad relationships, tend to have difficulty converting tensions and conflicts of interest into collaboration.

On the university side in Brazil, there is a fear of serving only the private interest of the company and not prioritizing the dissemination and knowledge sharing for the entire industry:

What's interesting to them [company], they will invest, of course. But then the research will be totally geared towards their goal, not to foster innovation for the whole industry, for the country. That's why I said that there is a lack of cooperation, because the negotiations are a bit isolated. You even have isolated cases [of cooperation], but it cannot be said that it is something characteristic of the industry (Agent Ubr2, 2017).

On the business side in Brazil, the idea is that the university is much closed and has no interest in sharing spaces (infrastructure) or in total or partial search results. In addition, it is stated that the university in Brazil generates "a lot of paper and little innovation" and is too interested in basic research:

[...] many laboratories in American universities, for example, you go there, you kind of lease the space, the laboratory structure, a laboratory assistance service and researchers to perform a specific analysis you need for your project. This is very cheap [...] and this culture we have difficulty in developing (in Brazil) [...] And then, what happens, it turns out that the driver of occupancy of these equipment (in Brazil) is more academic and then we keep doing what we have in Brazil, which is to generate a lot of paper and little innovation and this is a problem. So he [university lab] can think, "ah, but if I open here for business and provide service, run small service, maybe I will not have equipment for a larger service when I need or for a particular use of a researcher of us ... ", this is a resistance that we have to open, a reality that we have to change (Agent Ebr1, 2017).

The perception that the Brazilian university resists to collaborate is also shared by a government agent:

So, it is (the idea) that the university does not have to mess with a company. That still exists, okay? Even institutions that have a history of partnership, you will find most of the professors in these institutions that are against. The guy wants to do his basic research, wants to do the science he understands that will be more valuable, instead of actually looking for something more applied (Agent Gbr1, 2017).

For Swedes, the problem of agent interaction appears at a more advanced level. The central point is not the lack or insufficiency of collaboration, but rather how to deal with its effects, especially the intellectual property issue of innovations:

Another problem we face in Sweden is the ownership of innovations. Because everything is done in collaboration and partnership, there is a problem of who holds the project later (from the creation of such an innovation) (Agent Eswe3, 2017).

Another challenge for the promotion of innovation in the mineral industry identified by both Swedes and Brazilians was the lack of social acceptance of the mining activity. Mining has a dramatic history-large-scale pollution, destruction of indigenous peoples and ecosystems, drastic change in local livelihoods, among other problems. Although the regulation of the activity

\footnotetext{
${ }^{8}$ The problem of intellectual property resulting from the execution of collaborative projects between agents also appears in the Brazilian report: "Another issue that is also difficult to deal with in this partnership is the issue of intellectual property" (Agent Gbr1, 2017).
} 
and the possibilities that the innovations offer allow foreseeing a different future for the mining, the activity continues to be viewed with distrust by the society. This is the perception of Swedish and Brazilian agents:

And this because there is a culture that mining is evil, does not bring anything good. So, mining has always been left very sideways (Agent Ebr3, 2017).

Finally, the mining companies are opening up as something that really worries them, which is the relationship of the miners with the communities. It is often a somewhat ambiguous relationship, because at the same time that the mining company generates jobs, generates income in towns, it is polluting and, in the end, can generate accidents, as it happened ... (Agent Ubr3, 2017).

I think our industry and our company have the same problem as any other international mining company. As you know from a number of points of view, mining is not an attractive business because we affect the society around the mines... So of course we try to influence politicians to understand the need for mining (Agent Eswe2, 2017).

Well, overall in the (mining) area I would say we have a bit of ... even if the government is mostly promining, we have the issue of social acceptance ... and it has been pretty painful recently, so I guess this is kind of ... for the industry this (acceptance) is an issue (Agent Gswe3, 2017).

\section{CONCLUSION}

The agenda of priorities of the innovation policy for the mineral industry in Brazil is very focused on the industrial and technological issues, with some progress in the environmental sense and no evolution detected in the social sense. The environmental advance is due to the recently launched Inova Mineral, 2016, a reactive initiative to the Mariana accident, which encourages innovations to protect the environment around the mines.

When the Brazilian agenda is compared to the Swedish agenda, the differences are striking. In the interviews with the Swedish agents, the thesis is clear that the priorities of the innovation policy for the mineral industry must go beyond the purely technological dimension. The Swedish strategy is focused on the development of mining regions not only sustainable from a strictly environmental point of view, but also from the social point of view. Emphasis is given to innovations that generate attractive work environments in the mines, training of those who work there, gender equality at work and social conditions adequate in the environment.

The innovation policy for the Brazilian mineral industry can be characterized as ephemeral, uncertain, linked to only a certain government, little structured. There is little connection between the initiatives (Inova Mineral, PNM-2030, ENCTI). There is a lack of continuity of actions. The initiatives are not long-term. In the Swedish case, the agents also identify the difficulty of maintaining lasting actions as an obstacle to innovation in the industry.

The literature of the Triple Helix Model points out that interaction, collaboration among agents, is the key to generating innovation. What is observed in the Brazilian case is that there are tensions, schisms and distrusts in the relationship between companies and universities and government. On the university side, there is a fear of serving only the private interest of the company. On the business and government side, it is argued that the university is very closed, generates "too much paper and little innovation" and is too interested in basic research. The Swedes do not point out problems in the interaction between the agents. They report that cooperation occurs frequently. However, they highlight the challenge of dealing with the issue of intellectual property when innovation projects are developed cooperatively.

For both Brazilian and Swedish agents, the lack of social acceptance of the activity is pointed out as an obstacle to the policy of promoting innovations in the industry. For the different agents of the two countries, the mining activity continues to be viewed with distrust by society.

Historically considered an economic activity of a purely exploratory nature ("a curse"), in Brazil, mining has as challenge not only to promote product and process innovations that ensure productivity increase (business competitiveness), diversification 
of the productive chain, expansion of exports and import substitution (industrial policy), but also to promote non-technological innovations that ensure environmental preservation and social development. By proposing "socially sustainable mining regions", the Swedish experience of innovation promotion for the industry seeks to meet the challenge of low social acceptance of the activity and makes a potentially relevant contribution to Brazilian mining. The Swedish experience shows that cooperation among stakeholders is important and which thematic areas should be prioritized, as social and environmental guidelines, in the innovation policy for mining in Brazil.

As the main recommendations for innovation policy for the mineral industry in Brazil, comparative analysis with the successful case of Sweden suggests that: a) the existence of cooperation between the three agents (government, university, company) is a fundamental means for the promotion of innovation, therefore, it is necessary that the marked difficulties that such cooperation finds in Brazil must be overcome; $b$ ) the Brazilian innovation agenda is designed to include not only innovations related to the product and production process, but especially those related to environmental issues; and c) especially, the inclusion of innovations related to social issues, as a way to overcome the low acceptance of mineral activity revealed by Brazilian society. 


\section{REFERENCES}

ANDERSEN, A., D.; JOHNSON, B. The possibility of natural resourcebased development and the inadequacy of development theory. Aalborg: Aalborgh University, 2011.

BANCO NACIONAL O DESENVOLVIMENTO - BNDES; FINANCIADORA DE ESTUDOS E PROJETOS - FINEP. Edital de seleção pública conjunta BNDES/FINEP: Plano de Desenvolvimento, Sustentabilidade e Inovação no Setor de Mineração e Transformação Mineral - Inova Mineral. Brasília, DF: BNDES/FINEP, 2016.

BARDIN, L. Análise de conteúdo. São Paulo: Ed. 70, 2016.

BERGER, P. L.; LUCKMANN, T. The social construction of reality: a treatise in the sociology of knowledge. New York: Anchor, 1967.

BRASIL. Plano Nacional de Mineração 2030. Brasília, DF: Ministério de Minas e Energia, 2011.

BRASIL. Estratégia Nacional de Ciência, Tecnologia e Inovação 20122015. Brasília, DF: Ministério da Ciência, Tecnologia e Inovação, 2012.

BRASIL. Estratégia Nacional de Ciência, Tecnologia e Inovação 20162019. Brasília, DF: Ministério da Ciência, Tecnologia e Inovação, 2016.

CORNELL UNIVERSITY; INSEAD; WIPO. The Global Innovation Index 2016: winning with global innovation. 2016. Available at: <http:// www.globalinnovationindex.org>. Accessed on: Feb. 06, 2017.

DEPARTAMENTO NACIONAL DE PRODUÇÃO MINERAL - DNPM. Informe Mineral: julho a dezembro de 2016. 2016. Available at: <http://www.dnpm.gov.br/dnpm/publicacoes/serie-estatisticas-eeconomia-mineral/informe-mineral/publicacoes-nacionais/informemineral-2016-2o-semestre>. Accessed on: Sept. 10, 2017.

EDQUIST, C.; BORRÁS, S. Competence building: a system approach to innovation policy. In: CRESPI, F.; QUATRARO, F. (Org.). The economics of knowledge, innovation and systemic technology policy. Abingdon: Routledge, 2014. p. x-y.

EDQUIST, C.; BORRÁS, S. Competence building: a system approach to innovation policy. 2003. (Working paper, n. 28). Available at: $<$ https://www.researchgate.net/publication/269928733_Competence Building_A_Systemic_Approach_to_Innovation_Policy>. Accessed on: Nov. 10, 2017.

ETZKOWITZ, $\mathrm{H}$. The triple helix of university-industry-government: implications for policy and evaluation. 2002. Available at: <http:// www.sister.nu/pdf/wp_11.pdf>. Accessed on: Nov. 17, 2017.

ETZKOWITZ, H.; LEYDESDORFF, L. The triple helix - university-industrygovernment - relations: a laboratory for knowledge-based economic development. 1995. Available at: <https://www.researchgate.net/ publication/241858820>. Accessed on: Apr. 12, 2017.

ETZKOWITZ, H.; RANGA, M. Triple helix system: an analytical framework for innovation policy and practice in the knowledge society. 2012. Available at: <http://www.researchgate.net/publication/262009893>. Accessed on: Nov. 09, 2018.

ETZKOWITZ, H.; ZHOU, C. Hélice Tríplice: inovação e empreendedorismo universidade-indústria-governo. Estudos Avançados, v. 31, n. 90, p. 23-48, 2017.
FAGERBERG, J. Innovation policy: in search of a useful theoretical framework. 2015a. Available at: <http://www.sv.uio.no/tik/InnoWP/ tik_working_paper_20150321.pdf>. Accessed on: Apr. 21, 2017.

FAGERBERG, J. Innovation policy, national innovation systems and economic performance: in search of a "useful" theoretical framework. 2015b. Available at: <http://www.janfagerberg.org/wp-content/ uploads/2015/10/2015-Atlanta-Fagerberg-innovation-policy-1.pdf>. Accessed on: Mar. 17, 2017.

GEOLOGICAL SURVEY OF SWEDEN. Swedish ore mines. [2013]. Available at: <http://www.sgu.se/en/mineral-resources/swedishore-mines/>. Accessed on: Oct. 20, 2016.

GOVERNMENT OFFICES OF SWEDEN. Sweden's Mineral Strategy. 2011. Available at: <http://www.government.se/49b757/ contentassets/78bb6c6324bf43158d7c153ebf2a4611/swedens-minerals -strategy.-for-sustainable-use-of-swedens-mineral-resources-thatcreates-growth-throughout-the-country-complete-version>. Accessed on: Feb. 03, 2017.

GOVERNMENT OFFICES OF SWEDEN. The Swedish Innovation Strategy. 2012. Available at: <http://www.government.se/informationmaterial/2012/10/the-swedish-innovation-strategy/>. Accessed on: Feb. 03, 2017.

INNOVATION POLICY PLATFORM - IPP. OECD, World Bank. [2013]. Available at: <https://www.innovationpolicyplatform.org/content/ policy-goals-and-means>. Accessed on: Feb. 09, 2017.

INSTITUTO BRASILEIRO DE MINERAÇÃO - IBRAM. Informações sobre a economia mineral brasileira 2015. 2015. Available at: <http:// www.ibram.org.br/sites/1300/1382/00005836.pdf>. Accessed on: Jan. 31, 2017.

LKAB. Annual and Sustainability Report. 2015. Available at: <https:// www.lkab.com/globalassets/dokument/finansiell-information/en/ annual-reports/lkab_2015_annual_and_sustainability_report.pdf>. Accessed on: Feb. 02, 2017.

MESQUITA, P.P. D.; CARVALHO, P. S. L.; OGANDO, L. D. Desenvolvimento e inovação em mineração e metais. BNDES Setorial, n. 43, p. 324361, 2016.

MILANEZ, B.; LOSEKANN, C. (Org.). Desastre no Vale do Rio Doce. Antecedentes, impactos e ações sobre destruição. Juiz de Fora: Folio Digital, 2016.

MYERS, M. D. Qualitative research in business \& management. London: Sage, 2013.

NEGRI, J. A.; KUBOTA, L. C. Políticas de incentivo à inovação tecnológica no Brasil. Brasília, DF: Ipea, 2008.

ORGANISATION FOR ECONOMIC CO-OPERATION AND DEVELOPMENT - OECD. Innovation Policy Report 2006 - Switzerland. 2006. Available at: <http://www.oecd.org/science/inno/37631312.pdf>. Accessed on: Aug. 17, 2017.

ORGANISATION FOR ECONOMIC CO-OPERATION AND DEVELOPMENT - OECD. Innovation for development. 2012. Available at: <www. oecd.org/innovation/inno/50586251.pdf>. Accessed on: Apr. 09, 2017. 
PAMPLONA, J. B.; CACCIAMALI, M. C. Recursos naturais e estratégias de desenvolvimento para a América Latina. Estudos Avançados, v. 31, n. 89, p. 251-270, 2017.

SALERNO, M. S.; KUBOTA, L. C. Estado e inovação. In: NEGRI, J. A.; KUBOTA, L. C. (Org.). Políticas de incentivo à inovação tecnológica no Brasil. Brasília, DF: Ipea, 2008. p. 13-64.

SVEMIN. A vision of growth for the Swedish mining industry. 2012. Available at: <http://www.hannansreward.com/reports/121016Svemin_minirapport_eng_5.pdf>. Accessed on: Jan. 31, 2017.

THE SWEDISH TRADE \& INVEST COUNCIL. Metals \& mining in Sweden (sector overview): business opportunities in a mineral rich and underexplored region. Stockholm: The Swedish Trade \& Invest Council, 2016.

UNITED NATIONS COMTRADE DATABASE - UN COMTRADE. International Trade Statistics Database. [2014]. Available at: <https:// comtrade.un.org/>. Accessed on: Jan. 25, 2017.
US GEOLOGICAL SURVEY - USGS. Sweden Mining Report 2012 e 2014. 2012. Available at: <https://minerals.usgs.gov/ minerals/pubs/country/2012/myb3-2012-sw.pdf>. Accessed on: Jan. 30, 2017.

VINNOVA. Strategically important knowledge areas. [2018]. Available at: <https://www.vinnova.se/en/m/strategic-innovationprogrammes/>. Accessed on: Feb. 06, 2017a.

VINNOVA. Strategic Research and Innovation Agenda for the Swedish Mining and Metal Producing Industry. 2013. Available at: <http:// www.sipstrim.se/wp-content/uploads/2014/06/Agenda-STRIM-LTUVinnova.pdf $>$. Accessed on: Feb. 25, 2017b.

WORLD BANK. Innovation Policy: a guide for developing countries. 2010. Available at: <https://openknowledge.worldbank.org/bitstream/ handle/10986/2460/548930PUB0EPI11C10Dislosed061312010.pdf>. Accessed on: Mar. 24, 2017.

João Batista Pamplona

ORCID: https://orcid.org/0000-0002-6799-2476

PhD in Social Sciences from the Pontifical Catholic University of São Paulo (PUC-SP); Associate Professor at Post-graduation Program in Political Economy at Pontifical Catholic University of São Paulo (PUC-SP / PEPGEP); Professor at Post-graduation Program in Administration at Municipal University of São Caetano do Sul (USCS/PPGA), São Paulo - SP, Brazil. E-mail: pamplona@pucsp.br; pamplona@uscs.edu.br

Ana Carolina Penha

ORCID: https://orcid.org/0000-0002-2334-4995

Master in Political Economy from the Pontifical Catholic University of São Paulo (PUC-SP), São Paulo - SP, Brazil. E-mail: carolina.penha@gmail.com 